一踊 文—

（日本化学会誌，1988，（5)，p. 763～770）

(C) 1988 The Chemical Society of Japan

\title{
菜外線照射下でのオゾンによるエチレングリコールの分解
}

(1987 年 6 月 22 日受理)

满栖 信 行*・辰已起间

. 柴外線照射下でのオゾンによるエチレングリコールの分解を，エチレングリコール濃度 $1.6 \sim 8.0 \times$ $10^{-8} \mathrm{~mol} \cdot \mathrm{dm}^{-8}$, オゾン送入浱度 $5.3 \sim 15.6 \mathrm{mg} \cdot \mathrm{dm}^{-3}$, 紫外線照射強度 $13.3 \sim 18.6 \mathrm{~mW} \cdot \mathrm{cm}^{-8}$ のもと で行なった。

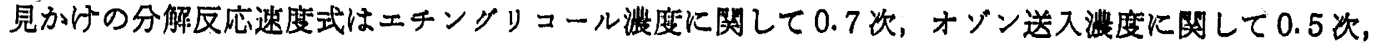
紫外線炤射強度に関して 2.6 次で表わされた。反応生成物としては 6 種の物筫が梌出されるとともに，

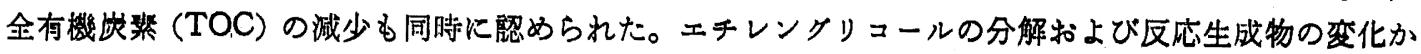
ら分解経路を推定した。TOC の減少過程においてはシュウ酸およびギ酸を経る経路の 2 通りが考えら

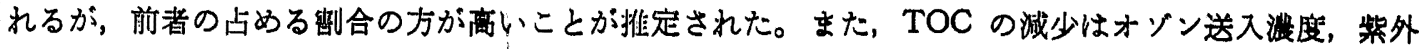
線照射強度のほかにェチレングリコール澧度によっても影響を受けることがわかった。

\section{1 腥}

近年上水の水贸瑟化にともないオソンが注目されておりり，上水 処理ブロセスの行処理や归阔処理として用いられている”。しか しながら，有機化合物に対するオン゙ンの酸化作用は期択的であ ク，一般にはこれら有機化合物を二酸化此策や水にまで完全に筑 機化させることは困難とされている。そのため，他の処理技術と の併用により酸化力を增大させる方法が行なわれている。著者ら はその一手法として踝解法との例用によるェチレンクリコールの 分解を行ない,オンン酸化法のみでは不可能であった全有機战桨

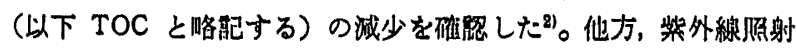
を例用することによっても酸化分解がいちじるしく促進されるこ

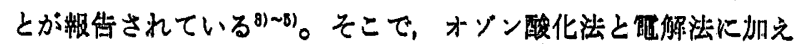
てさらに紫外線照射を作用すればより强い酸化分解能の発現が期 得できる。しかし、これに間する級告ははとんど見あたらないの。

一厅，オンン酸化法と紫外線沼射との侀用に和いては，水溶液

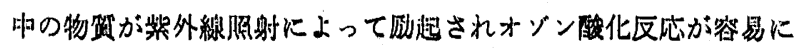
進行する。これはオン゙ンが紫外線 $(254 \mathrm{~nm})$ を忣収して酸染分子

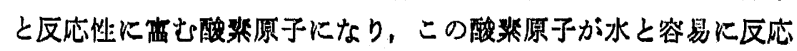
して生成されるヒドロキシルラシシカル $(\cdot \mathrm{OH})$ が有機化合物の酸

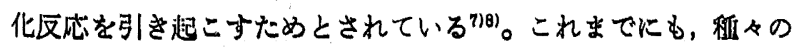
有機化合物の分解に対して紫外線照射下でのオンン酸化法（以下

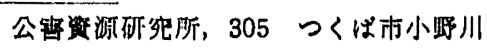

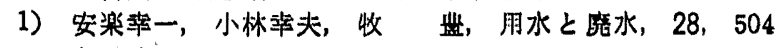
(1986).

2）满满信行，香月 収，日化，1987，743.

3) H. W. Prengre, J, C. G. Hewes, C.E. Mauke, Paper presented at 2 nd Int. Ozone Symp., Int. Ozone Inst., Montrral, Canada (1975).

4) 若生治，日化，1976，1530.

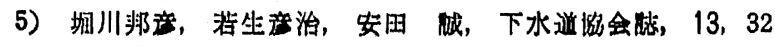
(1976).

6）高满作行，日特公昭 61-028396 (1986).
オソンー柴外線照射法と略肜する）が適用されてきておりり名，反

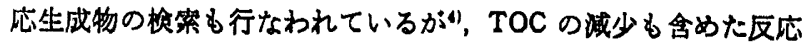
生成物の怪㭙变化や反応機楼などに関しての赤告はあまり行なわ れていない。

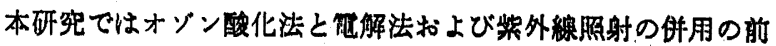
段階として，オンン一柴外線照射法による酸化分解奻果，とくに

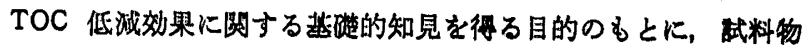

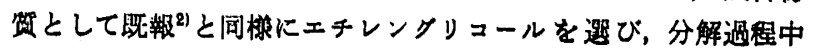
での反応生成物の顿䇣㧍よび縉時变化，分解機機，分解条件など の怜时を行なった。

\section{2 实跨}

\section{1 试落およひ调製}

エチレングリコールおよび反纫生成物のらち，クリコールフル

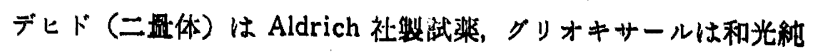
楽製化学用，グリオキシル酸は同社製一級武来，そのほかの物筫

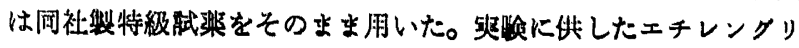
コール溶液は $1.6 \times 10^{-8}, 4.0 \times 10^{-3}, 8.0 \times 10^{-8} \mathrm{~mol} \cdot \mathrm{dm}^{-3}$ になる よらに瞅製して使用した。

\section{2 英瑍装}

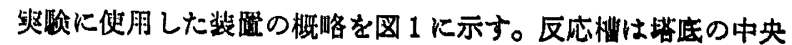
部に内部兴射型低正水銀灯を，また，同心円状に 4 储のガラスボ

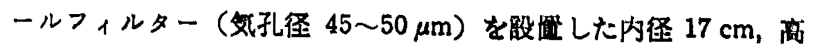
さ $65 \mathrm{~cm}$ のパイレックスガラス製円话である。オソンを含むガ スの発生には酸承ガスを健用し、ガス送钢量を $5.0 \mathrm{dm}^{3} \cdot \mathrm{min}^{-1}$ とし，オン゙ン発生機（日林オン゙ン制 NG-O $60,80,100 \mathrm{~V}$ としてオン゙ン峧度を调些した。このオン゙ン化ガスを

7) R. G. W. Norrish, R.P. Wayne, Proc. Roy. Soc., $A$, 288, 361(1965).

8) H.W. Prengre, Jr, Environ. Sci. Technol., 17, 743 (1983). 


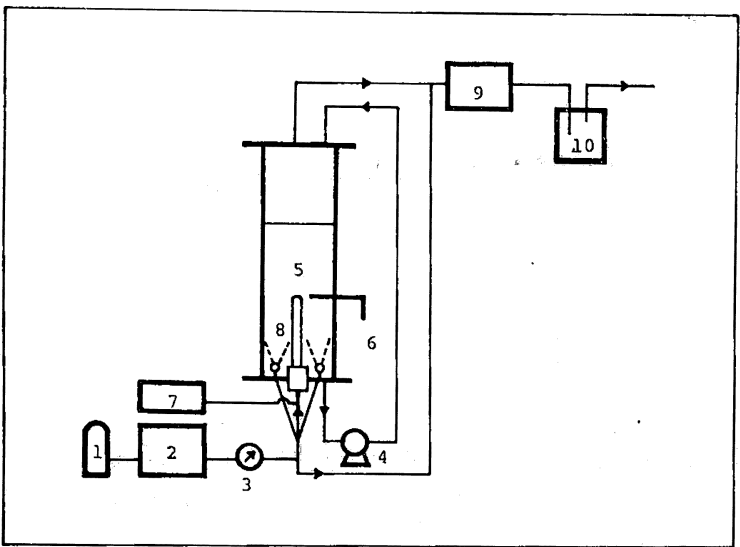

Fig. 1 Schematic diagram of ozone-ultraviolet irradiation method

1: Oxygen gas holder, 2 : Ozone generator, 3 : Flow meter, $4:$ Pump, $5:$ Reaction tower, $6:$ Sampling stopcock, $7:$ Low pressure mercury lamp, $8:$ Power supply for lamp, 9: Ozone meter, 10: Exhaust ozone gas absorption tower

ガラスボールフィルターを通して反応溶液中に送気し, 反応溶液 と気液接触させることによりオゾン酸化を行なった。気液接触後 のオゾン化ガスはヨウ化カリウム溶夜を入れた吸収塔を通してか ら大気中に排気した。送入オン゙ン濃度をオン゙ンメーター（萑原奏 業製 EG-101X 型) により測定したところ，放電電圧を 60,80 , $100 \mathrm{~V}$ と高くするにつれてオゾン送入濃度は高くなり，その濃度 はそれぞれ 5.3,11.8,15.6 mg・dm ${ }^{-3}$ であった。紫外線照射は内 部照射型低圧水銀灯 $20,60,120 \mathrm{~W}$ (英光社製 $\mathrm{EL}-\mathrm{J}$ 型) により 行なった。 $254 \mathrm{~nm}$ に拈ける紫外線強度は, 紫外線強度計 (UVP 社製デジタル UVX 型) で測定したところ，それぞれ 13.3， $16.8,18.6 \mathrm{~mW} \cdot \mathrm{cm}^{-2}$ であった。いずれの実験においてす， 1 回 あたりの反応溶液は $10 \mathrm{dm}^{3}$ であり, $\mathrm{pH}$ 未調整, 初期温度 $20 \pm$ $2^{\circ} \mathrm{C}$ のもとで 3 時間の反応を行なった。

\section{3 分析方法}

エチレングリコールならびに庈応生成物の検出には高速液体クロ マトグラフ (HPLC) (日立製 $635 \mathrm{~A}$ 型) を用い, 検出器として日 立製波長可変 UV モニター（検出波長 $210 \mathrm{~nm}$ ) および昭和電工 製示差屈折計 (RI) SE-31 型, カカラムとして昭和電工製 Shodex Ionpack C-811 使用 し, 溶離液 $0.1 \%$ リン酸水溶液, 流速 $1.0 \times 10^{-8} \mathrm{dm}^{-3} \cdot \mathrm{min}^{-1}$ ，カラム温度 $40^{\circ} \mathrm{C}$ で分析を行なった。一 定時間ごとに得られた反応溶液について，オン゙ン酸化法ならびに オゾンー紫外線照射法においては溶存オゾンによる反応の進行を 防ぐため採取後窒素ガスを吹き込み（紫外線照射法では採取後そ のまま), HLPC K $20 \times 10^{-6} \mathrm{dm}^{3}$ 注入した。反応生成物の同定 は標準物質のピーク保持時間との比較により行なった。定量は前 もって標準物質を用いて作製した検量線にしたがい行なった。な お，これと同時に，TOC を全有機炭素分析計（東芝ベックマン 製 102 型）により測定した。

\section{3 結 果と考察}

\section{1 反応速度式の検討}

エチレングリコールのオゾン-紫外線照射法による分解の見か
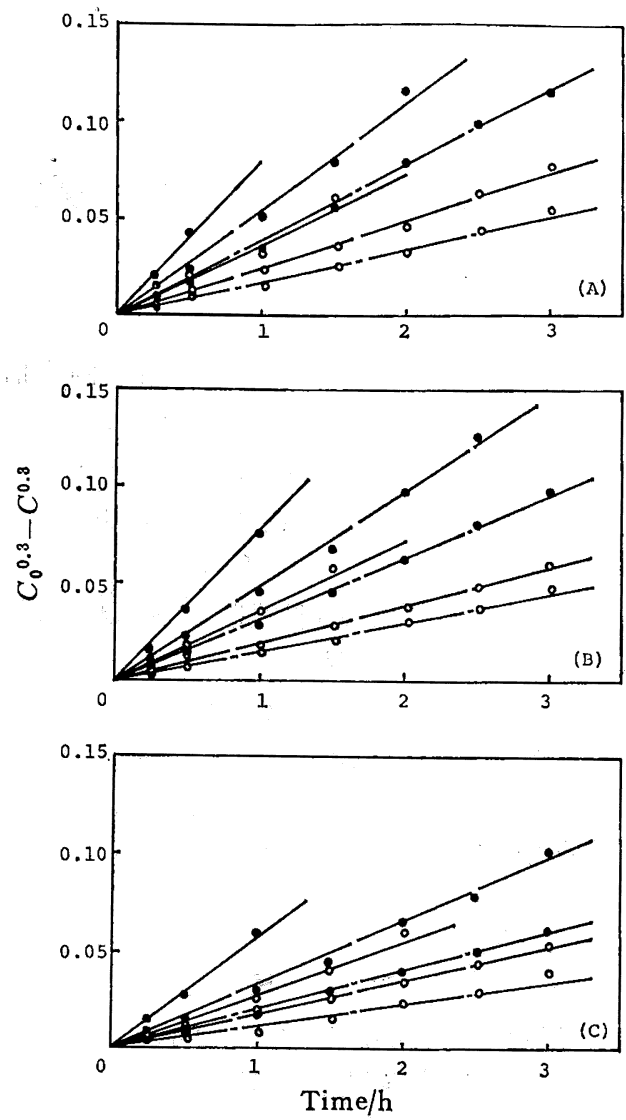

Fig. 2 Relationship between $\left[C_{0}{ }^{0.3}-C^{0.3}\right]$ and time

Discharge potential/V: (A) ; 100, (B) ; 80, (C) ; 60 Low pressure mercury lamp/W: $\bigcirc ; 120, O ; 20$ Concentration of ethylene $\mathrm{glycol} / \mathrm{mol} \cdot \mathrm{dm}^{-3}$ :

- $1.6 \times 10^{-3}, \perp-; 4.0 \times 10^{-3}$ $; 8.0 \times 10^{-3}$

けの反応速度式を求めるため, エチレングリコール滥度，オゾン 送入濃度, 紫外線照射強度を変化させて, 初竖度のピーク面積か らの減少により所定時間ごとの分解量を求めた。 $n$ 次反応に扣け る反応速度式に拈いて $n=0.7$ と仮定し, 各反応条件下に扣ける $C_{0}{ }^{0.3}-C^{0.3}$ (ここで, $C_{0}$ および $C$ は時間 $t=0, t$ におけるェチ レングリコール濃度）と $t$ の関係をプロットした皇。結果を図 2 に示す。罒からオゾン送入濃度怙よび紫外線照射強度が一定の場 合には土チレングリコール濃度が低いほど，エチレングリコール 濃度括よび紫外線照射強度が一定の場合にはオゾン送入濃度が高 いはど, エチレングリコール濃度扎よびオゾン送入濃度が一定の 場合には紫外線照射強度が高い注ど分解が促進されることがわか る。むた，いずれの反応条件下に括いてもプロットがほぼ楾に 乗ることから，エチレングリコール濃度の次数を 0.7 とする上の 仮定は成立することが示された。この結果, 見かけの分解反応速

9）ある特定な条件下に括いて Powell・プロットを行なった ところ， $n=0.7$ と仮定した場合の曲線にもっともよく合 致した。つきに, $n=0.7$ と仮定した場合の各条件下に拈 ける $C_{0}^{0.3}-C^{0.3}$ と $t$ の関係をプロットし, 直楾性を確認 した. 日本化学会䋧, “新実䀧化学䛾座 (反応と速度)”, 丸善 (1978) p. 39 . 


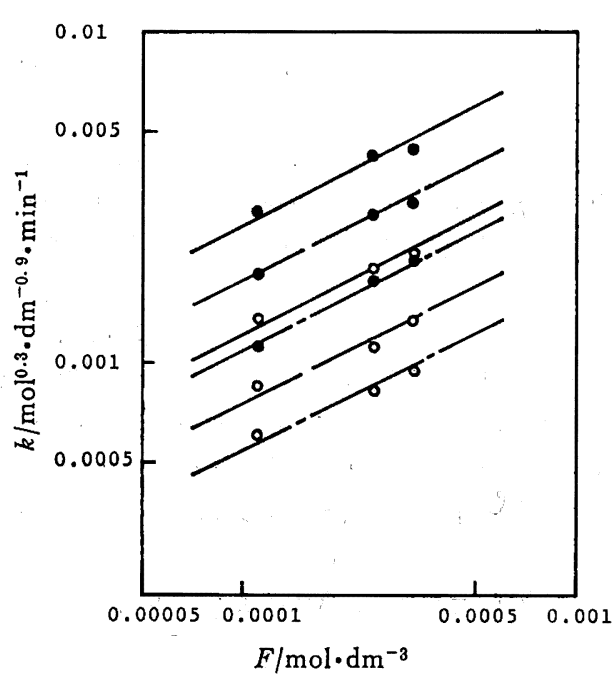

Fig. 3 Relationship between overall rate constant and concentration of ozone in the feed gas

Law pressure mercury lamp/W: $; 120,0 ; 20$ Concentration of ethylene $\mathrm{glycol} / \mathrm{mol} \cdot \mathrm{dm}^{-3}$ :

$$
\begin{aligned}
& -; 1.6 \times 10^{-3} \text {, —— } ; 4.0 \times 10^{-3} \text {, } \\
& --\longrightarrow ; 8.0 \times 10^{-3}
\end{aligned}
$$

度式は（1）式で表わされることがわかった。

$$
-\frac{\mathrm{d} C}{\mathrm{~d} t}=k C^{0.7}
$$

オン゙ン送入濃度 $F$ と見かけの反応速度定数 $k$ との関係を求める ため，各条件下に拈ける $k$ の值を図 2 のプロットから求めた。図 3 に $k$ との関係を示す。いずれの条件下に怙いてもほほ平行な 直線が得られており，Fおよび紫外線照射強度が高くなるにつれ て $k$ が大きくなることがわかった。これらの直線の傾きはいずれ

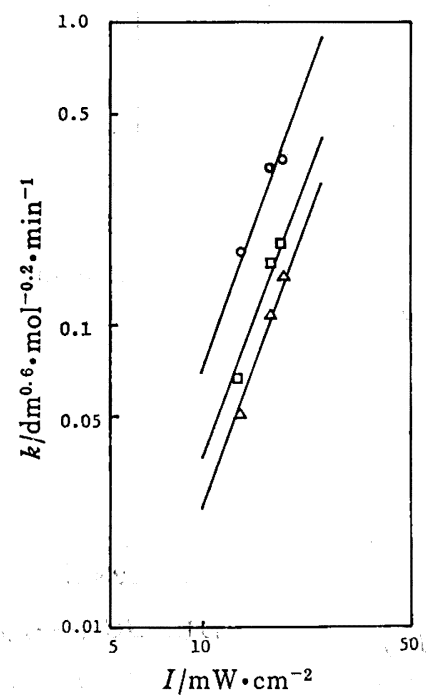

Fig. 4 Relationship between overall rate constant and irradiation intensity of low pressure mercury lamp at $254 \mathrm{~nm}$

Concentration of ethylene $\mathrm{glycol} / \mathrm{mol} \cdot \mathrm{dm}^{-3}$ : O $1.6 \times 10^{-8}, \square ; 4.0 \times 10^{-3}, \triangle ; 8.0 \times 10^{-3}$
もほほ 0.5 であることから（1）式は（2）式のように表わさ れる。

$$
-\frac{\mathrm{d} C}{\mathrm{~d} t}=k F^{0.5} C^{0.7}
$$

また，図 3 に拈ける各紫外線照射強度 $I$ のむとでの $k$ の值を求 め, それらと $I$ との関係をブロットしたところ図 4 が得られた。 その結果， $I$ が大きくなるとともに $k$ む大きくなることが示され るとともに，良好な直線性が認められており，この直線の傾きは ほほ2 2.6 であった。このことから，（2）式は（3）式のように表

$$
-\frac{\mathrm{d} C}{\mathrm{~d} t}=k I^{2.8} F^{0.5} C^{0.7}
$$

わされる。（3）式から，エチレングリコールのオゾンー紫外線照 射法による見かけの分解反応速度式はエチレン゙グリコール濃度に 関して 0.7 次, オン゙ン送入濃度に関して 0.5 次; 紫外線照射強 度に関して 2.6 次で表わされることがわかっだ10)。のことか ら，見かけの分解反応の速度はエチレングリコール濃度およびオ ゾン送入濃度に比較して紫外線照射強度に大きく影響されること
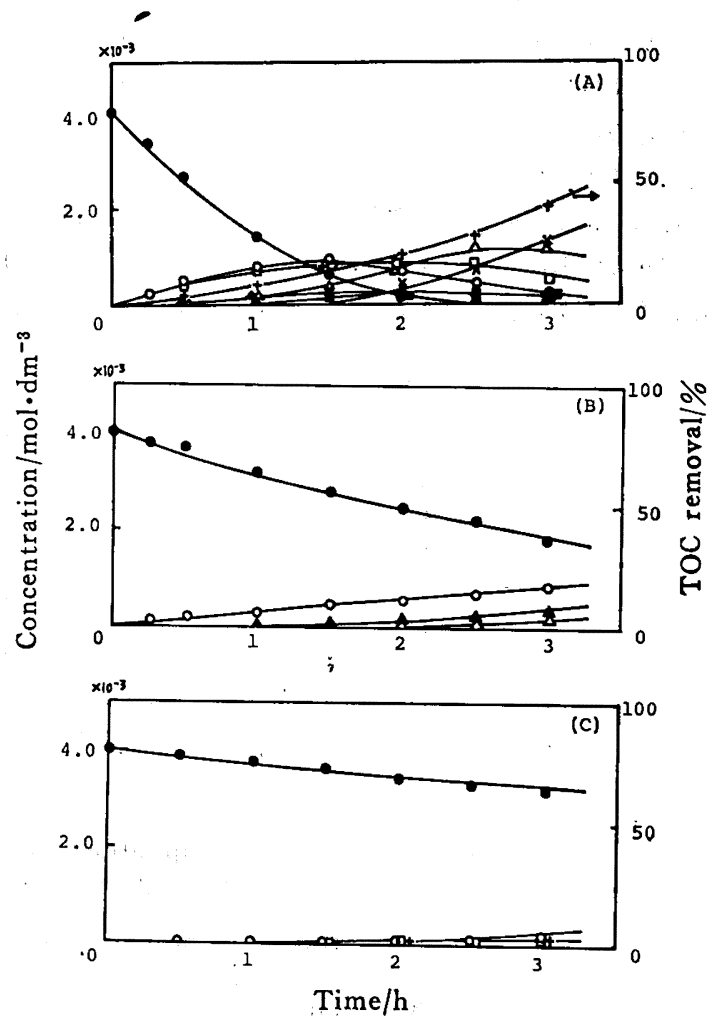

Fig. 5 Decomposition of ethylene glycol and change of its reaction products by ozone-ultraviolet irradiation method (A), ozone oxidaton method (B) and ultraviolet irradiation method (C) at initial concentration $4.0 \times 10^{-8} \mathrm{~mol} \cdot \mathrm{dm}^{-3}$

(A) : Discharge potential $100 \mathrm{~V}$ under irradiation by $120 \mathrm{~W}$ low pressure mercury lamp

(B) : Discharge potential $100 \mathrm{~V}$

(C) : $120 \mathrm{~W}$ low pressure mercury lamp

: Ethylene glycol, $\bigcirc$ : Glycolaldehyde, $\mathbf{\Delta}$ : Glyoxal,

$\triangle$ : Glyoxylic acid, $\times$ : Oxalic acid, $\square$ : Formaldehyde,

$\square$ : Formic acid, + : TOC removal 
が示された。しかし，後に述べるが，紫外線照射だけでは分解が あまり進まない。したがって，この影響は紫外線照射そのもので はなく，紫外線照射によるオゾン分子からの・OH の生成が見か けの分解反応に大きな影響をおよぼすことが推定でさる。

\section{2 反応生成物の検索}

オゾンー紫外線照射法に拈いてェチンングリコール濃度，オゾ ン送入濃度, 柴外線照射強度を変化させて反応を行ない, 反応生 成物の検索を行なった。その結果, 示差屈折計によるクロマトグ ラム上の保持時間 $11.4,12.3,13.9,15.2$ および 17.4 分の位直に ピークが認められた。これらはグリオキシル酸, グリオキサー ル, グリュールアルデヒド，ホルムアルデヒド扰よ゙エチレング リコールに相当した。また，UVによるクロマトグラム上の保持 時間 8.9 および. 15.4 分の位置にもシュウ酸およびギ酸に相当す るピークが認められた。またここれら反応生成物と同時に TOC の減少が認められた。図 5 にオゾン一紫外線照射法によるエチレ ンクリリコールの分解に拈ける反応生成物の経時変化の一例を，才 ゾンによる酸化のみの場合（以下オゾン酸化法と略記する）执よ び紫外線照射のみの場合 (以下紫外線照射法と略記する) と比較 し示す。オゾン酸化法ではオゾン送入量が大きくなるほど分解は 進み,グリコールアルデヒド，グリオキサール，グリオキシル酸 が順次生成する。しかし，この場合シュウ酸の生成执よび TOC の減少は認められなかった。オン゙ンによる酸化ではシュウ酸の分 解は起こらず11，たとえ反応過程中でシュウ酸が生成されたとし ても, 脱二酸化炭素による TOC の減少は起こらないと推定され る ${ }^{12)}$ 。紫外線照射によってシュウ酸やギ酸を含む数種の化合物が 分解されることが報告されている18)。エチレングリコールの場合
にも分解が認められたが，その箾合は少なく，グリコールアルデ ヒド怙よびギ酸がごくわずかに認められたにすぎず，TOCの娍 少も微少であった。

さらに, これらの方法の分解能を検討するため, 反応生成物と して検出された各物質について分解速度および TOC の減少量を 测定した。オゾン一紫外線照射法, オン゙ン酸化法, 紫外線照射法 による分解速度をそれぞれ $R_{\mathrm{O}_{3}-\mathrm{UV}}, R_{\mathrm{O}_{3}}, R_{\mathrm{UV}}$ とし ${ }^{14)} ， R_{\mathrm{O}_{3}-\mathrm{UV}}$ と $R_{\mathrm{O}_{3}}, R_{\mathrm{O}_{3} \text { UV }}$ と $R_{\mathrm{UV}}$ の比較を行ない，絬果を図 6 に示す。 $R_{\mathrm{O}_{3} \text { UV }}$ は $R_{\mathrm{O}_{3}}$ の $1.4 \sim 5.1$ 倍程度であるが, エチレングリコー

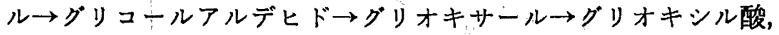

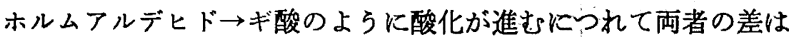
小さくなった ${ }^{15)}$ 。紫外線照射法との比校では, シュウ酸以外の各 物質では $R_{0_{3} \text {-Uv }}$ は $R_{\mathrm{UV}}$ の $11.4 \sim 60.0$ 倍であったが, シュウ 酸では 75.2 倍に增大した。各方法による TOC 除去率の結果の 一例を表 1 亿示す。オゾン酸化法ではホルムアルデヒドおよびギ 酸についてのみ，また，柴外線照射法ではいずれの物質について も TOC の娍少が認められるが，その程度は 5 19\% と低い。 これに対し，オゾン一紫外線照射法ではいずれの物質についても いちじるしいTOC’の減少が認められた。

このよらな分解促進効果が，オゾンのみならずオゾン化がス中 に混在する酸素によるとの可能性もある。そこで，紫外線照射下 でオゾン化ガスの代わりに酸素ガスを吹きこみながら反応を行な った。しかし, エチレングリュールの分解速度, 反応生成物の種 類および経時変化, TOC 除去率は紫外線照射法の場合とほとん ぞ変わらなかった。したがって，本反応涭外線 $(254 \mathrm{~nm})$ によ るオゾンの光分解により引き起こされるものと推定できる。以上

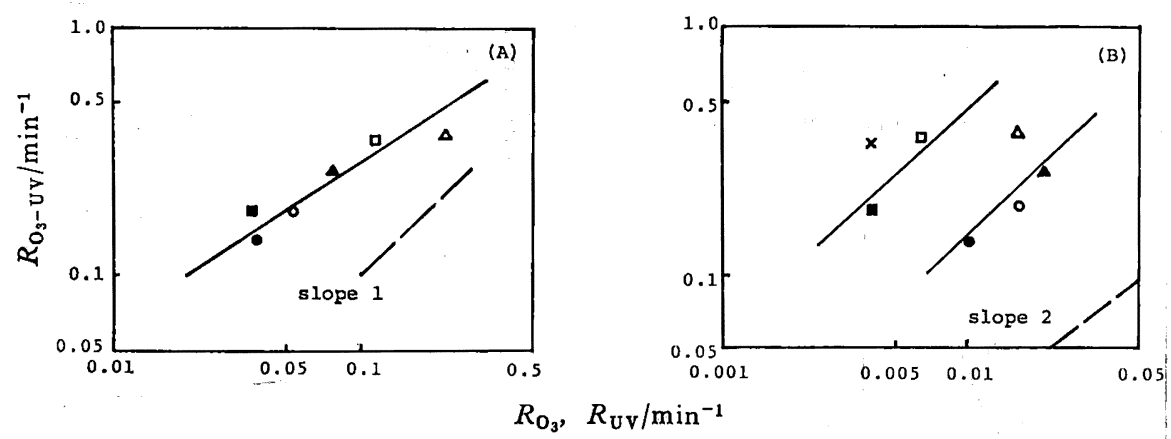

Fig. 6 Comparision of decomposition rate of ozone-ultraviolet irradiation method with that of ozone oxidation method (A) and that of ultraviolet irradiation method (B)

Concentration of ozone in the feed gas : $15.6 \mathrm{mg} \cdot \mathrm{dm}^{-3}$

Reaction time : $30 \mathrm{~min}$

: Ethylene glycol, $\bigcirc:$ Glycolaldehyde, $\Delta$ : Glyoxal, $\triangle:$ Glyoxylic acid, $x$ : Oxalic acid, $\square$ : Formaldehyde, $\square$ : Formic acid

10）紫外線照射下での酿酸扰よびシュウ酸のオソンによる酸化 分解飞就りる反応速度式として

$$
-\frac{\mathrm{d} C}{\mathrm{~d} t}=k\left[\mathrm{O}_{3}\right]_{1 \mathrm{~m}} I C^{n}
$$

が示されている.

池水喜義, 諸岡成治, 加藤康夫, 化学工学協会第19回秋季 大会予稿集, p.79 (1985).

11) Y. Yamamoto, E. Niki, H. Shiokawa, Y. Kamiya, J. Org. Chem., 44, 2137(1979).

12）化学大辞典編集委員会編，“化学大辞典”，共立出版 (1960) p. 908.
13) F. A. J. Armstrong, P. M. Williams, J. D. H. Strickland, Nature, 211, July, 481(1966).

14） $R=-\left(\frac{\Delta C}{\Delta t}\right) \cdot \frac{1}{\left[\mathrm{O}_{3}\right]}$ で表わし， $\Delta C$ は一定時間 $\Delta t$ 飞拉 ける分解量, $\left[\mathrm{O}_{3}\right]$ はオゾン送入濃度である.ここでは, オソン送入浱度 $15.6 \mathrm{mg} \cdot \mathrm{dm}^{-3}$ のもとでの 30 分反応後 の分解量の比較を行なった。

15） シュウ酸の $R_{\mathrm{O}_{3} \text {-UV }}$ は $30.8 \times 10^{-2}\left[\mathrm{~min}^{-1}\right]$ であるが，才 ゾン酸化法では分解されないため $R_{\mathrm{O}_{3}}$ は 0 である. 
Table 1 TOC removal by ozone-ultraviolet irradiation method, ozone oxidation method and ultraviolet irradiation method

\begin{tabular}{|c|c|c|c|c|c|c|c|}
\hline \multirow[b]{2}{*}{ Method } & \multicolumn{7}{|c|}{ TOC removal $/ \%$} \\
\hline & $\begin{array}{l}\text { Ethylene } \\
\text { glycol }\end{array}$ & $\begin{array}{l}\text { Glycol- } \\
\text { aldehyde }\end{array}$ & Glyoxal & $\begin{array}{c}\text { Glyoxylic } \\
\text { acid }\end{array}$ & $\begin{array}{l}\text { Oxalic } \\
\text { acid }\end{array}$ & $\begin{array}{l}\text { Form- } \\
\text { aldehyde }\end{array}$ & $\begin{array}{l}\text { Formic } \\
\text { acid }\end{array}$ \\
\hline $\begin{array}{l}\text { Ozone-ultraviolet } \\
\text { irradiation method }\end{array}$ & 42 & 98 & 100 & 100 & 100 & 100 & 100 \\
\hline Ozone oxidation method & 0 & 0 & 0 & 0 & 0 & 59 & 100 \\
\hline $\begin{array}{l}\text { Ultraviolet irradiation } \\
\text { method }\end{array}$ & 5 & 6 & 8 & 9 & 7 & 5 & 19 \\
\hline
\end{tabular}

Concentration of each material : $4 \times 10^{-3} \mathrm{~mol} \cdot \mathrm{dm}^{-3}$.

Reaction time : $3 \mathrm{~h}$.

Ozone-ultraviolet irradiation method: Discharge potential $100 \mathrm{~V}$ under irradiation by $120 \mathrm{~W}$ low pressure mercury lamp.

Ozone oxidation method: Discharge potential $100 \mathrm{~V}$.

Ultraviolet irradiation method: $120 \mathrm{~W}$ low pressure mercury lamp.

のように, オゾン酸化法ならびに紫外線照射法のそれぞれを単独 に用いた場合にくらべ，オゾン一紫外線照射法は強力な酸化分解 能を有することが確認できた。

\section{3 分解機構の検討}

エチレングリコールの分解機構を推察するだめ, 分解過程中で 検出された 6 種の物質のオゾンー紫外線照射法による分解におけ
る反応生成物および TOC 除去率の経時変化を調べた。その結果 を図 7 に示す ${ }^{16)}$ 。これから，グリコールフルデヒドは 2 時間前後 で完全に分解されたが，その過程でグリオキサール，クリオキシ ル酸, シュウ酸およびギ酸が生成した。シュウ酸以外の生成物は 2 時間でほぼ消隇したが, シュウ酸の生成量は 2 時間で最大にな った。そののち, 生成量は急速に減少し，これと対応する形で
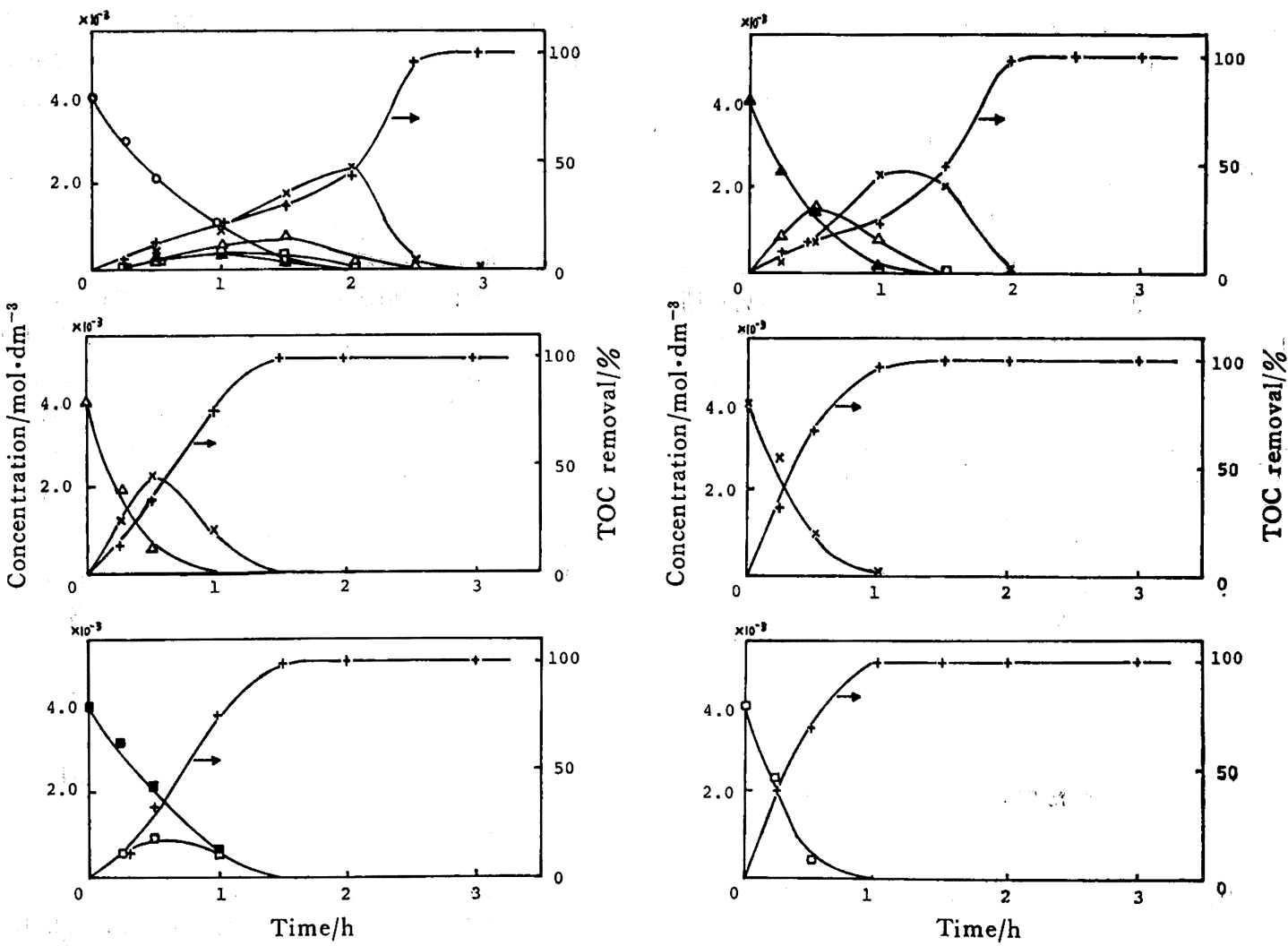

Fig. 7 Decomposition of various materials and change of their reaction products by ozone-ultraviolet irradiation method at discharge potential $100 \mathrm{~V}$ under irradiation by $120 \mathrm{~W}$ low pressure mercury lamp and initial concentration $4.0 \times 10^{-3} \mathrm{~mol} \cdot \mathrm{dm}^{-3}$

$\mathrm{O}$ : Glycolaldehyde, $\boldsymbol{\Delta}$ : Glyoxal, $\triangle$ : Glyoxylic acid, $\times$ : Oxalic acid,

$\square:$ Formic acid, + : TOC removal

16）分解速度および 3 時間反応後の TOC 除去率についてはすでに前に述べた。 
TOC 除去率は急速に上昇し，3時間では $100 \%$ となった。 た,グリオキサールは 1.5 時間前後で完全に分解された。この場 合グリオキシル酸およびシュウ酸が主生成物であり，これらは 0.5 時間および 1 時間前後で生成量が最大になるが, 1.5〜2 時間 後には完全に消隇した。なお，この時期に TOC 除去率は $100 \%$ となった。グリコールアルデヒド扰よびグリオキサールの分解に おいてキ酸が検出されたが，これは炭素一炭素結合の開裂で生じ たホルムアルデヒドが酸化され生成したものと思われる。エチレ ングリコールの分解ではホルムアルデヒドの生成が羿められた。 この生成物は, グリコールアルデヒドやグリオキサールの分解に おいては認められなかったことから、エチレングリコールの分解 によって直接生成されるるのと推定される。グリオキシル酸拉よ びホルムアルデヒドは 1 時間前後で完全に分解された。それぞれ の生成物はシュウ酸およびギ酸であり，それらの生成量は 0.5 洔 間前後で最大となった。また，1〜1.5 時間後に TOC 除去率は $100 \%$ となった。グリオキシル酸の紫外線照射法による分解では キ酸の生成が検出されることから ${ }^{17)}$, オン゙ン一紫外線照射法にお いてもホルムフルデヒドやキ酸の生成が尒想されるが, 生成速度 以上に分解速度が速いため, 分解過程中で検出されなかったるの と推定される。シュウ酸怙よびキ酸は 1 時間前後で完全に分解さ れたが，反応生成物は検出されなかった。シュウ酸の分解による 二酸化炭素の発生はギ酸を経由することが報告されているが ${ }^{12}$, 本実験ではシュウ酸の分解過程中でギ酸が検出されなかったこと から ${ }^{18)}$ ，本実験で認められたギ酸はホルムアルデヒドの酸化によ り生成されたるのと推定される。これらのことから，エチレング リコールのオゾンー紫外線照射法による分解経路および脱二酸化 炭素経路を推定し，図式 1 に示す19)。

エチレンクリコールの分解では, 出発物が 2.5 時間前後で完全 に消隇し，さきに述べた 6 種の生成物が分解完結時において検出 された。図 5 に示したようにシンウ酸以外の生成物は反応終期 には減少したが，シュウ酸は反応経過とともに增加した。また，

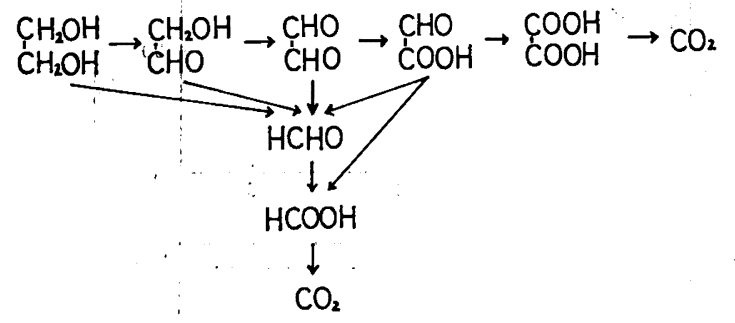

Scheme 1

17）分解過程中で検出された 6 魏の物質のそれぞれについて， オソン酸化法および紫外線照射法を適用し, 各物質の分解 飞おける度応生成物の経時变化扰よび TOC の減少を調へ た.その結果, グリオキシル酸ではシュウ酸およびギ酸の 生成が確認された。

18）キ酸の分解速度が速いため, 反応生成物として溶液中には とんど存在しないと推定される.

加藤康夫, 池水喜義, 諸岡成治, 化学工学論文集, 9, 104 (1983).

19）オソンー電解法ではクリコールフルデヒドーエチレンクリ コールキよびクリオキサールーグリコールアルデヒドの還 元反応が推定でき，シュウ酸やギ酸は生成物として検出さ れなかった. 文献 2).
TOC 除去率も反応経過とともに增加した。TOC の娍少過程とし てはシュウ酸扒よびギ酸を経る経路の 2 通りが考えられる（図式 1)。グリコールアルデヒド，グリオキサールおよびグリオキシル 酸の分解において，ホルムアルデヒドやギ酸は生成量が少ないか まったく検出されなかったことから，これら３物質では主として シュウ酸を経て脱二酸化炭素が起こるものと推定できる。一方, ホルムアルデヒドはギ酸を経る脱二酸化炭素が起こり得る。そこ で, シュウ酸を経て脱二酸化孷素を起こす物貿とキ酸を経て脱二 酸化炭䕀を起こす物質の分解過程中での濃度を計算すると, 前者 が後者に比较してかなり高く201，しかも，分解速度の差から予想 される以上の泎度差であること市，また，グリコールアルデヒ ド,グリオキサール，グリオキシル酸などではシェウ酸の娍少と TOC 除去率がよく対応していることなどから，TOC の減少過程 に执いてはシュウ酸を経る経路がより重要であると推定される。

紫外線照射下での酢酸のオゾンによる酸化分解において，炭酸 イオンによるヒドロキシルラジカルの捕捉効果により分解速度が 低下することが報告されている10)。したがって，TOC の減少が 炭酸イオンにより抑制されることが予想される。そこで, TOC 除去に拈よぼす $\mathrm{Na}_{2} \mathrm{CO}_{3}$ の添加量の効果を検討した。結果の一例 を図 8 に示す。 $\mathrm{Na}_{2} \mathrm{CO}_{3}$ の添加の有無によりシュウ酸の分解はい ちじるしい影響を受けた。すなわち、いずれの場合にもシュウ酸 の生成量は 1.5 洔間前後で最大となるすのの, 無添加の条件では シュウ酸はそれ以後急速かつ完全に分解された。これに対し，添 加した場合, その量が增すにつれてシュウ酸の分解速度は低下 し，そのため TOC 除去率も大きくは上昇しなかった。シュウ酸 の分解が阻害されると TOC 除去率の增加が緩慢になったこと は, TOC の娍少過程においてはシュウ酸を経る経路が重要であ るとするさきの推定を支持するむのである。

\section{4 反応条件の検討}

オゾン一紫外線照射法では反応条件のいかんにかかわらず，オ ゾン酸化法ならびに紫外線照射法と比較しすぐれた TOC 除去效

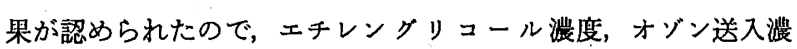
度, 紫外線照射強度などの反応条件が TOC の減少におよぼす影 響について検討した。その結果を四 9 に示す。オゾン送入浱度お よび紫外線照射強度を高くし，エチレングリコール浱度を低くす るほど高いTOC 除去率が達成でき，この条件下では，ェチレン グリコールを完全に二酸化炭素と水にまで分解することができ た。しかしながら，エチレングリコール濃度を高くすると TOC 除去率は低下し，オゾン送入濃度ならびに紫外線照射強度を增し ても高いTOC 除去率を得ることはできなかった。このよらに, TOC の除去はオゾン送入浱度, 紫外線照射強度のほかにェチレ ンクリコール裖度によっても影響を受けることがわかった。

20) 因5(A)の各時間に括いて, クリコールフルデヒド, クリ オキサール，クリオキシル酸扣よびシュウ酸の涭度と，木 ルムフルデヒド扣よびギ酸の濃度を比較すると， 1 時間で は 1.1 飞対して $0.8 ， 2$ 時間では 2.2 飞対し $1.4,3$ 時間 では 4.0 に対し $0.7 \times 10^{-3} \mathrm{~mol} \cdot \mathrm{dm}^{-3}$ である.

21）因7に打いて，14）で定義した分解速度

$$
R=-\left(\frac{\Delta C}{\Delta t}\right) \cdot \frac{1}{\left[\mathrm{O}_{3}\right]}
$$

を初期反応過程である反応後 30 分のもとで計算すると， シュウ酸では $30.8 \times 10^{-2}$, キ酸では $36.8 \times 10^{-2}\left[\mathrm{~min}^{-1}\right]$ である.このため, シュウ酸濃度としてキ酸滇度の約 1.2 倍存在すればよいことになる。 

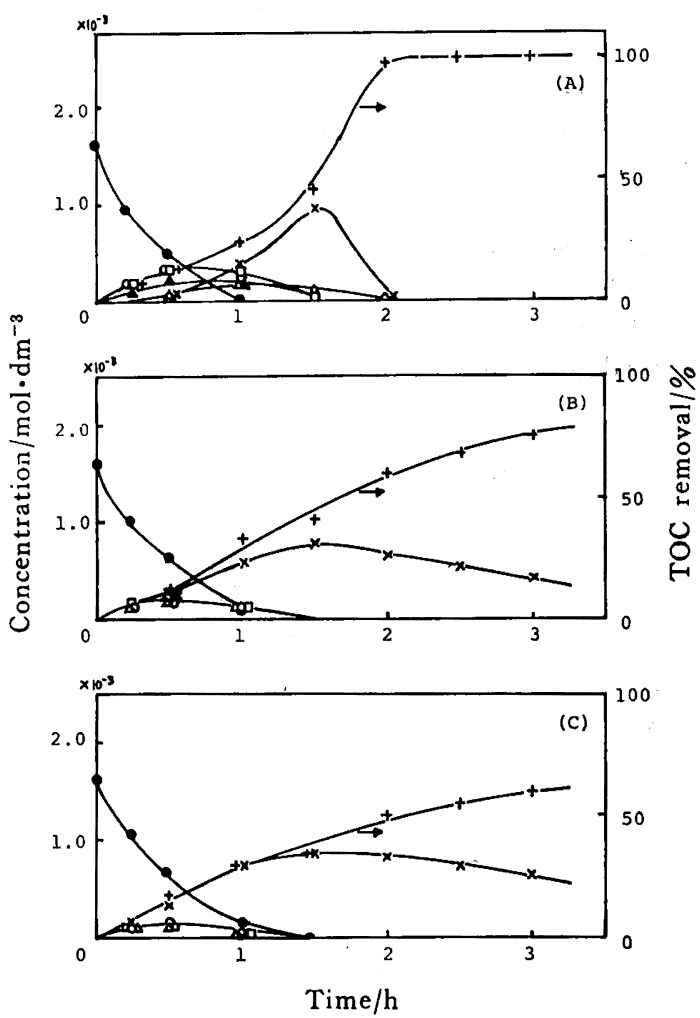

Fig. 8 Effect of $\mathrm{CO}_{3}{ }^{2-}$ on TOC removal at discharge potential $100 \mathrm{~V}$ under irradiation by $120 \mathrm{~W}$ low pressure mercury lamp and initial concentration 1. $6 \times 10^{-3} \mathrm{~mol} \cdot \mathrm{dm}^{-3}$

Quantity of $\mathrm{Na}_{2} \mathrm{CO}_{8} / \mathrm{g} \cdot \mathrm{dm}^{-3}:$ (A) ; 0, (B) ; 1.0 , (C) $; 2.5$

: Ethylene glycol, $\bigcirc:$ Glycolaldehyde, $\mathbf{\Delta}$ : Glyoxal, $\triangle$ : Glyoxylic acid, $\times$ : Oxalic acid, $\square:$ Formic acid, $+:$ TOC removal

\section{4 結 言}

オゾンー紫外線照射法によりェチレングリコールの分解を行な った。その結果，（1）見かけの分解反応速度式はエチレングリコ ール濃度に関して 0.7 次, オン゙ン送入濃度に関して 0.5 次, 紫
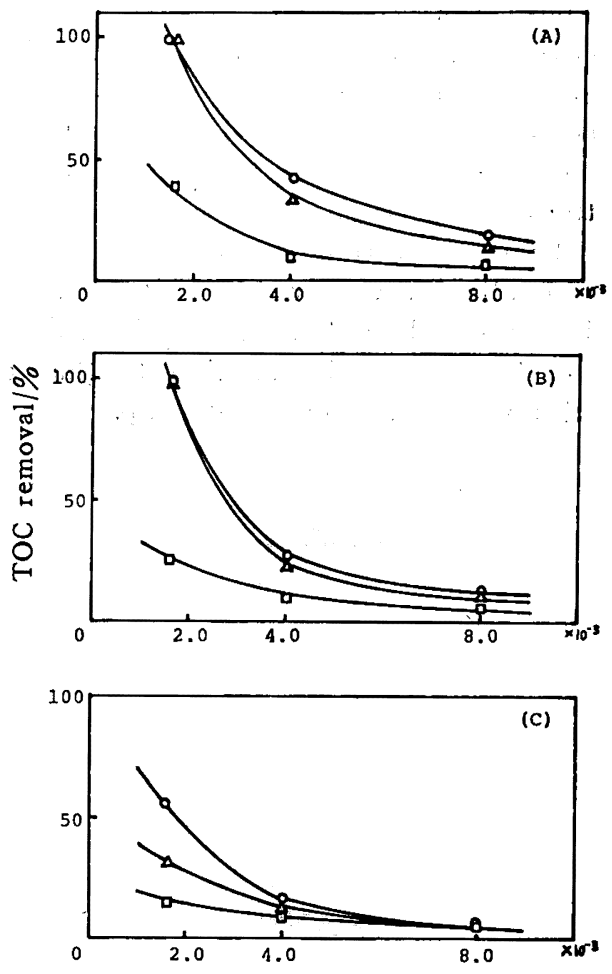

Initial concentration of ethylene glycol $/ \mathrm{mol} \cdot \mathrm{dm}^{-8}$

Fig. 9 Effects of reaction conditions on TOC removal Discharge potential/V: (A); 100, (B) ; 80, (C) ; 60 Low pressure mercury lamp/W : $\mathrm{O} ; 120, \triangle ; 60, \square ; 20$ Reaction time $: 3 / \mathrm{h}$

外線照射強度に関して 2.6 次で表わされること，（2）反応生成 物としてシュウ酸, グリオキシル酸, グリオキサール, グリュー ルアルデヒド，ホルムアルデヒドおよびギ酸の 6 種が検出される とともに, TOC の減少も認められること, (3) TOC の減少過 程においてはシュウ酸およびキ酸を程る経路の 2 通りが考えられ るが，前者の占める割合の方が高いこと，（4）TOC 除去はオン゙ ン送入濃度, 紫外線照射強度のほかにエチレングリコール漊度に よっても影響を受けることがわかった。

\section{Decomposition of Ethylene Glycol by Ozone under Ultraviolet Irradiation \\ Nobuyuki TAKahashi* and Kenji TAtsumi \\ National Research Institute for Pollution and Resources; \\ Onogawa, Tsukuba-shi 305 Japan}

Decomposition of ethylene glycol by ozone under ultraviolet irradiation was studied by changing the concentration of ethylene glycol, that of ozone in the feed gas, and the irradiation intensity of a low pressure mercury lamp.

The overall reaction rate was represented as follows.

$$
-\frac{\mathrm{d} C}{\mathrm{~d} t}=k I^{2.6} D^{0.8} C^{0.7}
$$


where $k$ is rate constant, $I$ is the irradiation intensity of a low pressure mercury lamp, $F$ is the concentration of ozone in the feed gas, and $C$ is that of ethylene glycol. Oxalic acid, glyoxylic acid, glyoxal, glycolaldehyde, formaldehyde and formic acid were detected as decomposition products, and the removal of total organic carbon (TOC) was observed too. Based on the decomposition behavior of ethylene glycol and change of its decomposition products, the decomposition route was estimated.

From the estimation of the decomposition route and the fact that a considerable amount of oxalic acid was produced, it was suggested that the TOC removal ria oxalic acid was more important than that via formic acid. The TOC removal was affected by the concentration of ethylene glycol in addition to that of ozone in the feed gas and the irradiation intensity of low pressure mercury lamp. 